\title{
Perubahan histologik pada usus besar hewan coba postmortem
}

\author{
${ }^{1}$ Clifford Lapian \\ ${ }^{2}$ Sunny Wangko \\ ${ }^{2}$ Djon Wongkar
}

\author{
${ }^{1}$ Kandidat Skripsi Fakultas Kedokteran Universitas Sam Ratulangi Manado \\ ${ }^{2}$ Bagian Anatomi Histologi Fakultas Kedokteran Universitas Sam Ratulangi Manado \\ Email: clifford.lapian@gmail.com
}

\begin{abstract}
Cell death occurs after somatic death. The aerobic process of cells would be halted as a result of somatic death, whereas the anaerobic process will continue. Therefore, the cells do not die in a short time although the oxygen supply has been depleted. This anaerobic process will have an impact on the morphology and activity of cells. This study was aimed to obtain the microscopic changes of large intestine for 24 hours postmortem. This was a descriptive observational study. A domestic pig weighed $20 \mathrm{~kg}$ was used as sample. The microscopic examinations were performed at several interval times as follow: 0 , $1,2,3,4,5,6,7,8,9,12,14,16,18,20,22$, and 24 hours postmortem. The results showed that the microscopic changes of the large intestine were identified the earliest at 2 hours postmortem as congestion with dilatation of the intestinal crypt lumen; lysis of a number of intestinal crypts at 6 hours postmortem; all intestinal crypts were lysis leaving empty areas; and the mucosal layer and intestinal crypts could not be identified at 24 hours postmortem. Conclusion: The earliest microscopic changes of the large intestine occured at 2 hours postmortem. Lysis of the intestinal crypts began at 6 hours postmortem and became complete at 12 hours postmortem.
\end{abstract}

Keywords: large intestine, postmortem, intestinal crypt

\begin{abstract}
Abstrak: Kematian sel terjadi setelah kematian somatis. Proses aerobik sel-sel akan terhenti akibat kematian somatis, sedangkan proses anaerobik akan tetap berlangsung. Hal tersebut mengakibatkan sel-sel tidak mati dalam waktu yang singkat meskipun pasokan oksigen telah habis. Proses anaerobik ini akan berdampak pada morfologi dan aktivitas sel. Penelitian ini bertujuan untuk mendapatkan perubahan gambaran histologik usus besar pada hewan coba selama 24 jam postmortem. Jenis penelitian ialah deskriptif observasional. Sampel penelitian ialah satu ekor babi domestik dengan berat $20 \mathrm{~kg}$. Pengamatan mikroskopik terhadap sampel dilakukan pada beberapa interval waktu, yaitu: 0 jam, 1 jam, 2 jam, 3 jam, 4 jam, 5 jam, 6 jam, 7 jam, 8 jam, 9 jam, 12 jam, 14, 16 jam, 18 jam, 20 jam, 22 jam, dan 24 jam postmortem. Hasil penelitian mendapatkan perubahan mikroskopik postmortem paling awal pada usus besar terjadi pada 2 jam postmortem berupa kongesti dengan lumen kripta Lieberkuhn yang berdilatasi; pada 6 jam postmortem tampak sebagian kripta Lieberkuhn telah lisis; pada 12 jam postmortem seluruh kripta Lieberkuhn telah lisis; dan pada 24 jam postmortem lapisan epitel dan kripta Lieberkuhn tidak dapat diidentifikasi lagi. Simpulan: Perubahan histologik postmortem paling awal pada 3 jam postmortem, lisis kripta Lieberkuhn telah tampak sejak 6 jam postmortem, dan menyeluruh pada 12 jam postmortem. Kata kunci: usus besar, postmortem, kripta Lieberkuhn
\end{abstract}

Mati ialah berhentinya semua fungsi vital tubuh secara permanen. Untuk kepentingan aspek medikolegal, maka digunakan definisi mati sebagai berhentinya semua 
fungsi otak, sistem respirasi dan sistem sirkulasi secara spontan tanpa bisa pulih kembali. $^{1} \quad$ Postmortem ialah keadaan setelah kematian.

Kematian sel terjadi setelah kematian somatis. Proses aerobik sel-sel akan terhenti akibat kematian somatis, sedangkan proses anaerobik akan tetap berlangsung. Hal tersebut mengakibatkan sel-sel tidak mati dalam waktu yang singkat meskipun pasokan oksigen telah habis. Proses anaerobik ini akan berdampak pada morfologi dan aktivitas sel. ${ }^{2,3}$

Dalam bidang forensik untuk perkiraan lama waktu kematian dapat digunakan pemeriksaan tanda-tanda kematian (algor mortis, rigor mortis, livor mortis, decomposition) dan pemeriksaan laboratorium (pemeriksaan histopatologik, serologik, toksikologik dan sebagainya). ${ }^{4,5}$

Dalam penelitian ini dilakukan pemeriksaan histopatologik usus besar dengan mengevaluasi perubahan morfologik postmortem. Keuntungan pemeriksaan histopatologik ialah pemeriksaan ini dapat digunakan pada keadaan-keadaan seperti: mayat ditemukan dalam keadaan tidak utuh atau termutilasi, maupun pada kasus dimana mayat ditemukan dalam keadaan terbakar sebagian. ${ }^{5,6}$

Organ dalam yang paling cepat membusuk termasuk otak, hati, lambung, usus halus dan limpa sedangkan organ yang lambat membusuk ialah paru-paru, esofagus, jantung, diafragma, ginjal, dan kandung kemih. ${ }^{7}$ Evaluasi gambaran histopatologik organ seperti jantung, ginjal, dan usus akan amat membantu memperkirakan saat kematian mengingat letak organ-organ tersebut yang terlindung dalam tubuh sehingga pengaruh lingkungan dapat dikurangi. ${ }^{5}$ Faktor lingkungan yang berpengaruh terhadap penentuan waktu interval postmortem termasuk suhu udara dan kelembaban. ${ }^{8}$

Dewasa ini penelitian histopatologik postmortem baik pada usus besar maupun organ lainnya untuk perkiraan lama waktu kematian belum bisa diaplikasikan dalam penyidikan. Diharapkan hasil penelitian ini dapat dikembangkan sehingga dapat diaplikasikan pada manusia untuk membantu prosses penyelidikan dan penyidikan dalam bidang forensik. Pada penelitian ini diamati perubahan yang terjadi pada gambaran histologik usus besar babi postmortem untuk perkiraan lama waktu kematian. Hewan coba yang digunakan ialah babi domestik karena babi termasuk hewan omnivora dengan struktur dan histofisiologi saluran cerna serta flora usus yang mirip manusia. ${ }^{9-11}$

\section{METODE PENELITIAN}

Jenis penelitian yang digunakan ialah penelitian deskriptif observasional. Penelitian ini dilakukan pada tanggal 15 Januari 2016, bertempat di Kelurahan Banjer. Sampel yang digunakan dalam penelitian ini yaitu babi domestik (sus domesticus) dengan berat $20 \mathrm{~kg}$, dan secara fisik sehat dan tidak ada riwayat penyakit.

\section{HASIL PENELITIAN}

Pengamatan mikroskopik dilakukan terhadap 17 sampel dengan menggunakan pembesaran 40x, 100x, dan 400x untuk menilai struktur epitel dan kripta Lieberkuhn. Pada 1 jam, postmortem belum tampak perubahan pada kripta Lieberkuhn. Pada 2 jam postmortem terlihat kongesti dan dilatasi lumen kripta Lieberkuhn. Pada 6 jam postmortem, terlihat sebagian kripta Lieberkuhn sudah mengalami lisis. Pada 12 jam postmortem, terlihat epitel permukaan dan seluruh kripta Lieberkuhn telah lisis. Pada 24 jam postmortem, struktur lapisan epitel dan kripta Lieberkuhn tidak dapat diidentifikasi lagi.

\section{BAHASAN}

Pada penelitian ini ditemukan perubahan histologik kolon hewan coba postmortem mulai tampak pada sampel 2 jam postmortem berupa kongesti dan dilatasi kripta Liberkuhn. Pada sampel 5 jam postmortem mulai tampak nekrosis sel epitel dan sebagian kecil kripta telah lisis. Gambaran kripta yang lisis makin meluas dan pada 12 jam postmortem seluruh kripta Lieberkuhn telah mengalami lisis. 


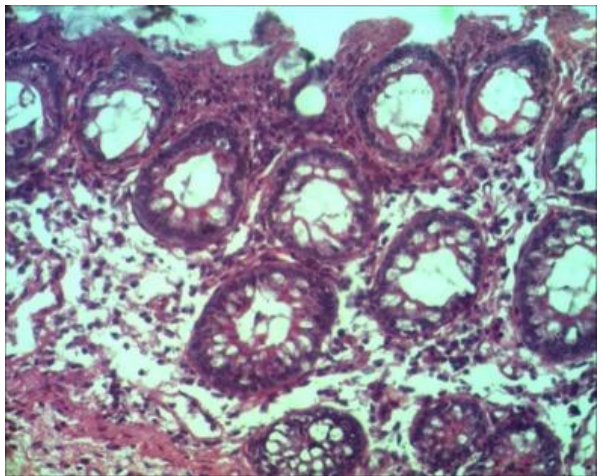

Gambar 1. Gambaran histologik kolon hewan coba 1 jam postmortem (400x). Kripta Lieberkuhn tampak normal.

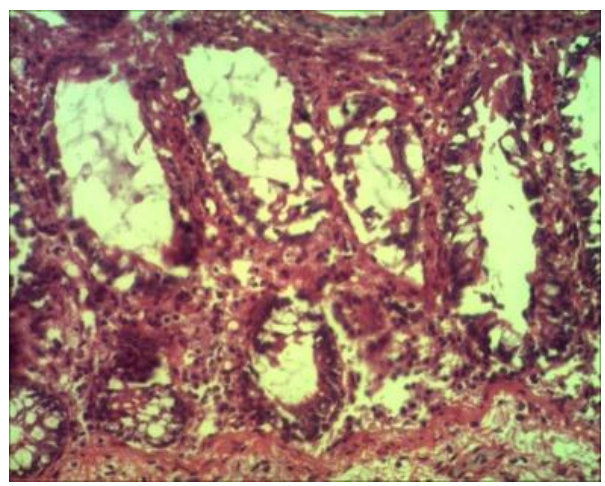

Gambar 3. Gambaran histologik kolon hewan coba 3 jam postmortem (400x). Dilatasi lumen kripta tersebar luas.

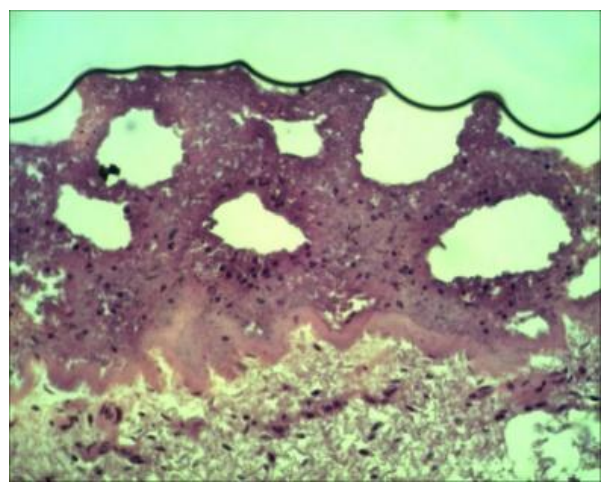

Gambar 5. Gambaran histologik kolon hewan coba 12 jam postmortem (400x). Seluruh kripta telah lisis.

Penelitian pada organ hepar babi postmortem yang dilakukan oleh Pualillin et al. ${ }^{12}$ menggunakan mikroskop cahaya mendapatkan perubahan histologik hepar postmortem muncul pada 30 menit ditandai kongesti parenkim hepar disertai dilatasi sinusoid. Hasil penelitian Rahmadana et al. ${ }^{13}$ terhadap organ ginjal babi postmortem

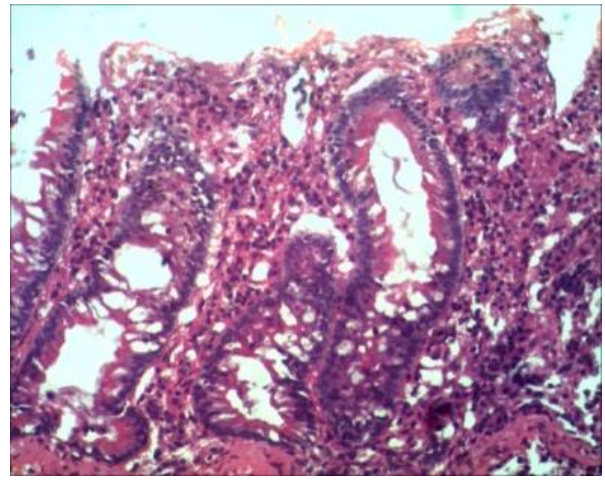

Gambar 2. Gambaran histologik kolon hewan coba 2 jam postmortem (400x). Tampak lumen kripta berdilatasi.

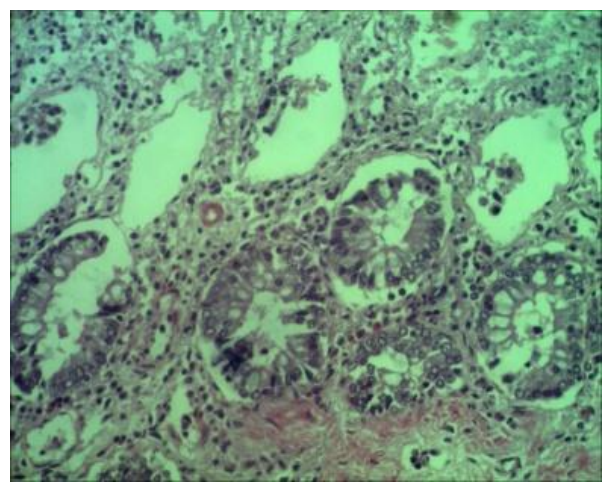

Gambar 4. Gambaran histologik kolon hewan coba 6 jam postmortem (400x). Sebagian kripta telah lisis meninggalkan ruang-ruang kosong.

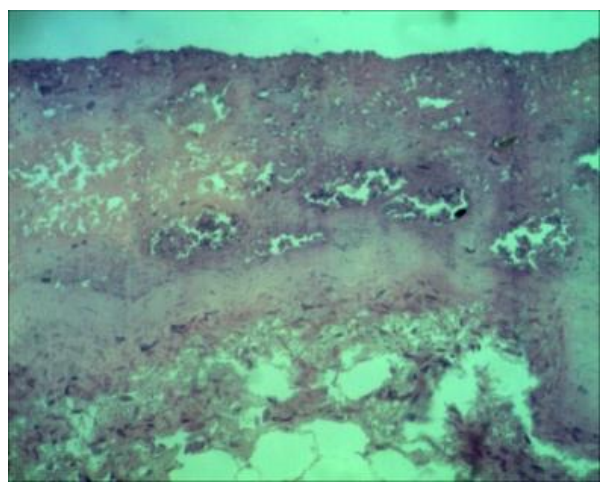

Gambar 6. Gambaran histologik kolon hewan coba 24 jam postmortem (400x). Lapisan epitel dan kripta tidak dapat diidentifikasi lagi.

dengan menggunakan mikroskop cahaya mendapatkan degenerasi hidropik tubuli proksimal merupakan perubahan histologik yang paling awal yaitu 30 menit postmortem. Penelitian yang dilakukan oleh Abeng et al. ${ }^{14}$ pada struktur kult babi postmortem menggunakan mikroskop cahaya mendapatkan perubahan histologik 
kulit muncul setelah 4 jam postmortem ditandai dengan kongesti epidermis, badan Meissner, dan sel Langerhans tidak dapat diidentifikasi, dan kariolisis sel-sel epidermis.

Karadzic $^{15}$ melakukan penelitian terhadap hepatosit manusia postmortem dengan menggunakan mikroskop elektron dan mendapatkan sebagian mitokondria mengalami pembengkakan pada 6 jam postmortem. Krenasi dan pemisahan vakuola dari membran nukleus, dislokasi nukleus, penggumpalan dan migrasi perifer dari kromatin, penonjolan mitokondria, serta fragmentasi krista mitokondria dalam jumlah yang besar pada hepatosit ditemukan pada 12 jam. Bagian luar dari membran mengalami lisis seddangkan bagian paling dalam nukleus terlihat utuh, lokasi periferal dari kromatin dalam bentuk cincin homogen yang tidak beraturan dalam kepingan berupa salju, lisis yang jelas dari krista mitokondria, serta lisis awal dari apparatus Golgi dan retikulum endoplasma ditemukan pada 24 jam postmortem.

Hasil dari beberapa penelitian di atas berbeda dengan penelitian ini yang menggunakan kolon hewan coba babi postmortem baik saat dimulainya terjadi perubahan mikroskopik, perlangsungan perubahan tersebut, serta bentuk perubahan yang terjadi. Perubahan awal pada gambaran histologik kolon babi postmortem terlihat pada sampel 3 jam yang menunjukkan sebagian epitel mulai mengalami kongesti sedangkan pada penelitian Rahmadana et al. ${ }^{13}$ menggunakan hepar babi postmortem, perubahan mikroskopik langsung terlihat pada 30 menit yaitu berupa kongesti parenkim hepar disertai dilatasi sinusoid. ${ }^{13}$ Selanjutnya sampel kolon babi 6 jam postmortem menunjukkan sel mengalami nekrosis sedangkan pada sampel hepatosit manusia 6 jam postmortem menunjukkan pembengkakan mitokondria.

Berdasarkan perbandingan hasil penelitian di atas, terdapat beberapa faktor yang dapat memengaruhi. Perbedaan suhu saat pengambilan sampel dari hewan coba dapat memengaruhi proses autolisis dari sampel organ. Berdasarkan penelitian Rajani didapatkan semakin tinggi suhu semakin cepat proses kematian sel. ${ }^{16}$ Perbedaan letak serta struktur organ juga bisa berpengaruh karena di dalam kolon terdapat lebih banyak bakteri aktif dari pada di dalam organ lainnya seperti hepar, ginjal, dan kulit. Bakteri yang berada di usus besar akan berkembang biak ketika keadaan sekitar menjadi anaerob. Hal ini juga dapat memerpcepat terjadinya proses dekomposisi dari organ.

\section{SIMPULAN}

Berdasarkan penelitian mengenai gambaran histologik usus besar pada hewan coba postmortem dapat disimpulkan bahwa perubahan histologik awal terjadi pada 2 jam postmortem berupa kongesti dan dilatasi kripta Lieberkuhn. Lisis sebagian kripta mulai diidentifikasi pada pada 6 jam postmortem yang menjadi menyeluruh pada 12 jam postmortem.

\section{SARAN}

1. Penelitian ini perlu dikembangkan dengan menggunakan organ-organ lain agar dapat diaplikasikan untuk kepentingan medikolegal

2. Perlu diperhatikan cara pengambilan sampel agar mendapatkan sediaan yang baik.

\section{DAFTAR PUSTAKA}

1. Death. Kamus Kedokteran Dorland (29 ed). Jakarta: EGC, 2002; p. 567.

2. Aldila A. Hubungan antara lama waktu kematian dengan kerusakan histopatologik otot jantung tikus wistar. 2010. [cited 2015 Oct 22]. Available from: http://eprints.undip.ac.id/2315/1/Arie _Aldila.pdf.

3. Fajar AR. Pengaruh perbedaan suhu dan lama waktu kematian terhadap kemampuan pergerakan silia cavitas nasi hewan coba postmortem. 2012 [cited 2015 Oct 22]. Available from: http://eprints.undip.ac.id/43858/2/Faj arAkbarR_G2A009180_BAB1.pdf

4. Pratama AA. Hubungan antara lama waktu kematian dengan kerusakan histo- 
patologik otot jantung tikus wistar. 2010. [cited 2015 Oct 22]. Available from:

core.ac.uk/download/pdf/11722157.p df

5. Indra P. Perbedaan kecepatan lisis sel ginjal tikus wistar pada media tanah dan air tawar: berdasarkan gambaran histopatologi. 2010.[cited 2015 Oct 22]. Available from: http://eprints.undip.ac.id/23650/1/Prar indra.pdf

6. Rahmanita M. Perbedaan kecepatan lisis sel hepar pada tikus wistar dalam media air tawar dan tanah: berdasarkan gambaran histopatologi. 2010. [cited 2015 Oct 22]. Available from core.ac.uk/download/pdf/11722556.p $\mathrm{df}$

7. Azis SF. Perbandingan antara durasi waktu pembekuan terhadap terjadinya pembusukan jaringan paru-paru pada kelinci. 2014. [cited 2015 Oct 22]. Available from: eprints.undip.ac.id/44885/

8. Wardhani DH, Teguh M. Penentuan perkiraan saat kematian [Refarat]. Manado: Universitas Sam Ratulangi; 2010.

9. Penggunaan babi dalam dunia kedokteran manusia. 2007.[cited 2015 Oct 22]. Available

from: http://repository.ipb.ac.id

10.Hampson DJ, Duhamel GE. Porcine colonic spirochetosis/intestinal spirochetosis. In: Straw BE, Zimmerman JJ, D'Allaire S, Taylor DJ, editors. Diseases of swine. Oxford: Blackwell Publishing, 2006; p. $755-83$.

11.Swidle MM, Smith AC. Comparative anatomy and physiology of the pig. SJLAS. 1998;25:11-22.

12.Pualillin NK, Wangko S, Kalangi SJR. Gambaran histologik hepar hewan coba postmortem. JBM. 2014;6(2):98-104.

13.Rahmadana B, Wangko S, Kalangi SJR. Gambaran histologik ginjal hewan coba postmortem. eBM. 2014;2(2):413-8.

14.Abeng KA. Gambaran struktur kulit hewan coba pada beberapa interval waktu postmortem. 2016. [cited 2016 May 27]. Available from: http://ejournal.unsrat.ac.id/index.php/ ebiomedik/article/view/10820/10409

15.Kadrazic R. Autolytic ultrastructural changes in rat and human hepatocytes. RJLM. 2010;18(4):24752.

16.Rajani T. A study on estimation of time since death after histological examination of kidney. International $\mathbf{J}$ Res Med Sci. 2015;3(5):1091-6. 